killer the doctor would be well advised to make certain that the preparation was not a dipyridyl type of herbicide before assuming that an early recovery from poisoning will be permanent. A sample of urine should be analysed as soon as possible, and if this shows that the patient has absorbed any significant amount of paraquat he should be treated, in the absence of any known specific measures, on general principles. These would include stomach wash-out and the promotion of diuresis by mannitol. If there are signs of renal failure, dialysis should be considered. Unfortunately no treatment has yet been found effective once the lung lesions develop.

\section{Allergic Alveolitis}

Mushroom-worker's lung, like bird-fancier's lung, ${ }^{1}$ is one of a group of pulmonary allergic diseases due to inhaled organic dusts, for which the term "extrinsic allergic alveolitis" has been suggested. Farmer's lung is the classical example.

The inhalation of organic dusts may cause two main forms of allergic disease, affecting either the bronchi, with the production of asthma, or the peripheral lung tissues, with the production of a mainly alveolar reaction. An analysis ${ }^{2}$ of the factors which determine these important differences shows that atopic persons give bronchial asthmatic reactions which are mediated by non-precipitating, reaginic antibody (type I allergy ${ }^{3}$ ), whereas non-atopic persons give predominantly alveolar reactions, provided the dust particles are small enough to penetrate to the alveoli. These reactions are mediated by precipitating antibody (type III allergy ${ }^{3}$ ).

Many organic dusts cause allergic alveolitis. The diseases include farmer's lung, ${ }^{4}$ bagassosis, ${ }^{5}$ maple-bark disease due to the fungus Cryptostroma corticale, ${ }^{6}$ lung disease due to the grain weevil Sitophilus granarius, ${ }^{7}$ bird-fancier's lung due to avian antigens, ${ }^{8}$ and pituitary snuff-taker's lung due to porcine and bovine posterior pituitary powder. ${ }^{9}$ In the B.M.F. this week (page 708) Dr. Alex Sakula adds another-namely, mushroom-worker's lung, due to actinomycetes that flourish in hot, damp vegetable matter. In all of these diseases precipitins have been found in the serum against the relevant antigens. Other similar diseases in which precipitins have either not yet been found or not certainly identified include suberosis due to cork dust, paprika-splitter's lung, smailpoxhandler's lung, ${ }^{10}$ and the chronic lung disease of New Guinea natives attributed to dust from thatched roofs. ${ }^{11}$

Extrinsic allergic alveolitis, whatever its cause, has a common pattern of clinical symptoms, all of them present in the patients suffering from mushroom-worker's lung. They are entirely different from the wheezing of the asthmatic patient, in whom pulmonary function tests show airways obstruction. Systemic reactions are an important feature of allergic alveolitis, and may consist of fever, chills, and malaise, with aches and pains, followed by a marked loss of weight. The pulmonary symptoms and signs are those of a chiefly alveolar reaction. They consist of cough, and of dyspnoea, which is often severe and out of proportion to the paucity of the crepitant rales which may be heard. Tests of pulmonary function show a restrictive defect, with impairment of gas transfer and decrease in lung compliance, with little, if any, evidence of airways obstruction. ${ }^{41213}$ Such tests are now becoming an essential part of the investigation of patients with lung disease.

Radiographic examination in the early stages usually shows nodular shadows, frequently micronodular, and of a wide distribution, as might be expected from the inhalation of large amounts of finely particulate dust capable of reaching the alveoli. In the late stages there is radiographic evidence suggestive of fibrosis, with diffuse honeycomb changes, affecting particularly the upper lobes.

Histological examination of the lungs shows, in the early stages, infiltration of the alveolar walls with polymorphonuclear, lymphoid, and plasma cells, and in the later stages epithelioid-cell granulomata and fibrosis are present. In about one-quarter of patients with farmer's lung bronchiolitis obliterans was also found. ${ }^{14}$

The disease may present in two ways. ${ }^{48}$ The classical form consists of systemic and pulmonary symptoms appearing five to six hours or more after exposure to the dust. Such attacks may subside rapidly, only to recur on re-exposure. The disease may also have an insidious onset and is then, if anything, the more dangerous, because the relationship of the symptoms to the causal exposure is far less likely to be suspected. The gradual development of the disease results in the patient's seeking medical attention when fibrosis is far advanced and irreversible. The differences in the mode of onset appear to be related to the frequency and intensity of exposure to the dust. Inhalation tests in both groups of patients provoke the same classical attacks of the disease, coming on after five to six hours or so. ${ }^{8}$

Management of the disease must be based on avoidance of the antigens. This makes it imperative that inhaled dusts should be considered as possible causes in patients with disease affecting the alveoli or with pulmonary fibrosis. Fortunately, the precipitin test offers a means of identifying the antigen, though the presence of precipitins can be taken in the first place only as evidence of exposure to the antigens. Inhalation tests help to confirm the cause by reproducing the disease, and when a new dust is recognized such tests are needed to establish the clinical relevance of the immunological findings. Once the significance of the serological tests has been established, inhalation tests may reasonably be omitted. Farmers can avoid exposure to thermophilic actinomycetes by keeping down the moisture content of the hay. ${ }^{15}$ Mushroom workers face greater difficulties, because in the making of their compost many actinomycete spores are inevitably produced. ${ }^{16}$ Masks are of limited value, because of the very small size of the spores of the thermophilic actinomycetesonly about $1 \mu$ in diameter. ${ }^{17}$

1 Brit. med. F., 1967, 2, 713.

Medical Research Council Annual Report, 1966-67, 1967, p. 74

H.M.S.O. $\log y, 1963$. Oxford

- Pepys, J., and Jenkins, P. A., Thorax, 1965, 20, 21.

Salvaggio, J. E., Seabury, J. H., Buechner, H. A., and Kundur, V. G., 7. Allergy, 1967, 39, 106 Emanuel, D. A., Wenzel, F. J., and Lawton, B. R., New Engl. F. Med.,

Lunn, J. A., and Hughes, D. T. D., Brit. F. industr. Med., 1967, 24, 158.

- Hargreave, F. E., Pepys, J., Longbottom, J. L., and Wraith, D. G., Lancet, $1966,1,445$

- Pepys, J., Jenkins, P. A., Lachmann, P. J., and Mahon, W. E., Clin. exp. Immunol., 1966, 1, 377.

Morris Evans, W. H., and Foreman, H. M., Proc. roy. Soc. Med., $1963,56,274$.

Blackburn, C. R. B., Lancet, 1966, 2, 1396.

Rankin, J., Jaeschke, W. H., Callies, Q. C., and Dickie, H. A., Ann. intern. Med., 1962, 57, 606.

13 Williams, J. V., Thorax, 1963, 18, 255

4 Emanuel, D. A., Wenzel, F. J., Bowerman, C. I., and Lawton, B. R., Amer. F. Med., 1964, 37, 392 .

Gregory, P. H., Festenstein, G. N., Lacey, M. E., Skinner, F. A. Pepys, J., and Jenkins, P. A., f. gen. Microbiol., 1964, 36, 429.

Pepys, J., and Jenkins, P. A., 7. gen. Micro
Fergus, C. L., Mycologia, 1964, 56, 267.

17 Corbaz, R., Gregory, P. H., and Lacey, M. E., f. gen. Microbiol. 1963, 32, 449.

1. Pepys, J., Longbottom, J L., and Jenkins, P. A., Amer. Rev. resp. Dis., 1964, 89, 842 . 
While in farmers and mushroom workers antigens from micro-organisms are the cause of the allergic alveolitis, it is worth noting that organic dusts from any source are possible causes of similar serious disease. There is evidence that precipitins are commonly present in persons exposed to a wide range of vegetable dusts. ${ }^{18}$

\section{Doctors for Industry}

There are about 2,000 appointed factory doctors in Britain, most of whom are general practitioners. They examine young persons entering industry, advise both the employer and the employee in cases where a disease or disability is likely to be affected by working conditions, and have various other statutory duties. Last year a Ministry of Labour report ${ }^{12}$ recommended that these part-time factory doctors should be replaced by a much smaller group of 100 " A doctors," still responsible to the Ministry of Labour.

The report has been the subject of much controversy, both among doctors in industry ${ }^{3}$ and elsewhere, and the Industrial Health Committee of the Royal College of Physicians ${ }^{5}$ has now commented on it. The Royal College report agrees " that the present Appointed Factory Doctor Service does not meet the needs of the working population," but goes on to point out that the envisaged 100 A doctors will serve only that part of the working population covered by the Factories Acts, whereas those covered by the Shops, Offices and Railway Premises Act will be left out, as will many other groups of workers, such as fishermen.

The Royal College report suggests that as the A doctors' role would be mainly to give advice they should answer to the Ministry of Health and not the Ministry of Labour. As well as emphasizing the advisory function of $\mathrm{A}$ doctors this would improve their career structure and facilitate their recruitment from the National Health Service, especially as they might be part-time in the first instance. A doctor could have secretarial assistance and trained ancillary services provided by the N.H.S. for carrying out radiological, physiological, and haematological investigations. The Royal College report suggests that an industrial hygiene service could be organized by regions, preferably based on the universities.

The most contentious proposal in the original report from the Ministry of Labour was that school doctors should issue all school-leavers with a standard certificate, which would make the examination at entry to industry unnecessary. The Royal College Committee agreed that the numerous young persons' statutory annual examinations at present carried out by the appointed factory doctors are largely a waste of time and took the view that the pre-employment medical certificate was a satisfactory substitute.

However, the B.M.A. Occupational Health Committee is far less happy with the idea of the certificate and has made its views known to the Minister of Labour. At any preemployment examination of a young person by an industrial medical officer or an appointed factory doctor, not only is the employer already chosen but the actual job that the schoolleaver is going to do is known to the examiner. If the School

\footnotetext{
The Appointed Factory Doctor Service. Report by a Subcommittee
of the Industrial Health Advisory Committee. H.M.S.O. 1966. 2 Brit. med. F., 1966, 2, 539.

Trans. Soc. occup. Med., 1966, 16, 37

- Ibid., 1967, 17, 81.

- The Appointed Factory Doctor Service, Report of the Royal College of Physicians, 1967.

- A Review of the Medical Services in Great Britain, Social Assay, London, 1962.
}

Medical Service issues a certificate of fitness for most leavers and a small group receives a "disabled" certificate it may lead to the employer deciding which jobs are "heavy" or have a "high dermatitis hazard," and may also make it easy for an unscrupulous employer to refuse all but the healthy school-leavers. This is an interference with the individual's freedom to apply for any sort of occupation which he himself chooses, and another step in the creation of a State dossier on each citizen. This restriction is to be foisted on schoolleavers as part of an inescapable administrative scheme, and is based only on the evidence of a school doctor at the beginning of this person's working career. The doctor may err, or the patient's condition may improve.

The solution put forward by the B.M.A. is that a handbook should be issued for the guidance of school medical officers, listing the medical handicaps which might be hazardous for school-leavers in open industry. Young persons with these disabilities could be referred to the A doctor for his advice. He could then take the matter up with the general practitioner and the youth employment officer and eventually with the proposed employer.

The Association of Certifying Factory Surgeons, which is the recognized body of the appointed factory doctors, has not yet committed itself to print but seems to be viewing its members' demise with equanimity, while at the same time regretting that all the emphasis has been placed on the timewasting statutory examinations of young persons and that no mention has been made of the valuable service that appointed factory doctors have already carried out in the field of occupational health.

However, the climate of expert opinion appears to favour the appointment of $\mathrm{A}$ doctors, if they will become occupational health advisers under the Ministry of Health serving on area health boards as envisaged by the Porritt Committee. ${ }^{6}$ These men could then become the basis of a national occupational health service, a service which the Treaty of Rome demands in a field where Britain lags behind most other civilized countries.

\section{Treatment of Addicts}

The Dangerous Drugs Bill was introduced to "provide for the control of drug addiction." Moving the second reading in April, Miss Alice Bacon ${ }^{1}$ claimed that the Bill paved the way for a major change in the organization of treatment for addicts. Fundamental to that change was the establishment of treatment centres in hospitals. However, until there are enough of these centres to cope with the number of cases there is no possibility of getting away from the existing practice of individual doctors prescribing heroin and other drugs as they see fit.

Government spokesmen have repeatedly stated that plans for the provision of these centres are proceeding smoothly, and that they hoped that the regulations limiting prescription of drugs to addicts would be introduced in 1968. But the Ministry of Health has refused ${ }^{2}$ to provide hospital boards with the money for treatment centres, and there is little evidence that they are being established. The Ministry refuses to name the hospitals where the centres are to be or to give any details of their progress. The existing out-

\footnotetext{
Brit. med. 7., 1967, 2, 187.

2 Ibid., 1967, 3, 58.

Edwards, G., ibid., 1967, 3, 425

- Ibid.. 1967. 2, 498.
} 